\title{
Plutonium Immobilization Project (PIP) Precursor Material Calcine Temperature
}

by

\author{
A. D. Cozzi \\ Westinghouse Savannah River Company \\ Savannah River Site \\ Aiken, South Carolina 29808 \\ J. C. Marra
}

DOE Contract No. DE-AC09-96SR18500

This paper was prepared in connection with work done under the above contract number with the U. S.

Department of Energy. By acceptance of this paper, the publisher and/or recipient acknowledges the U.S. Government's right to retain a nonexclusive, royalty-free license in and to any copyright covering this paper, along with the right to reproduce and to authorize others to reproduce all or part of the copyrighted paper. 
WSRC-TR-99-00053, Revision 0

PLUTONIUM IMMOBILIZATION PROJECT (PIP) PRECURSOR MATERIAL CALCINE TEMPERATURE EVALUATION (U)

\author{
A.D. Cozzi and J.C. Marra
}

Publication Date: June 30, 1999

Westinghouse Savannah River Company

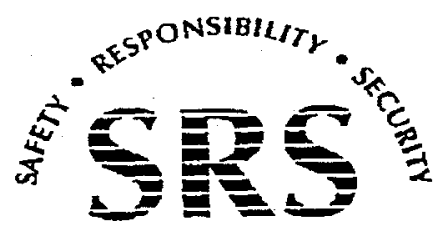


WSRC-TR-99-0053, Revision 0

\section{DISCLAIMER}

This report was prepared as an account of work sponsored by an agency of the United States Government. Neither the United States Government nor any agency thereof, nor any of their employees, makes any warranty, express or implied, or assumes any legal liability or responsibility for the accuracy, completeness, or usefulness of any information, apparatus, product, or process disclosed, or represents that its use would not infringe privately owned rights. Reference herein to any specific commercial product, process, or service by trade name, trademark, manufacturer, or otherwise does not necessarily constitute or imply its endorsement, recommendation, or favoring by the United States Government or any agency thereof. The views and opinions of authors expressed herein do not necessarily state or reflect those of the United States Government or any agency thereof.

This report has been reproduced directly from the best available copy.

Available to DOE and DOE contractors from the Office of Scientific and Technical Information, P.O. Box 62, Oak Ridge, TN 37831; prices available from (615) 576-8401.

Available to the public from the National Technical Information Service, U.S. Department of Commerce; 5285 Port Royal Road, Springfield, VA 22161. 


\section{DISCLAIMER}

Portions of this document may be illegible in electronic image products. Images are produced from the best available original document. 
WRSC-TR-99-0053, Revision 0

WSRC-TR-99-00053, Revision 0

Distribution Category: Unlimited

Keywords: Plutonium, Immobilization, Precursor, Calcine

Retention: Permanent

PLUTONIUM IMMOBILIZATION PROJECT (PIP) PRECURSOR MATERIAL CALCINE TEMPERATURE EVALUATION $(U)$
A.D. Cozzi
J.C. Marra

Publication Date: June 30, 1999 
WSRC-TR-99-0053, Revișion 0

Approvals

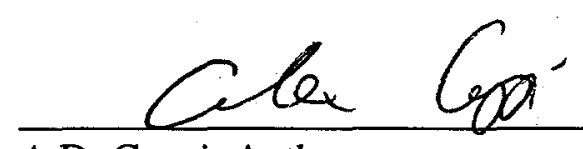

A.D. Cozzi, Author

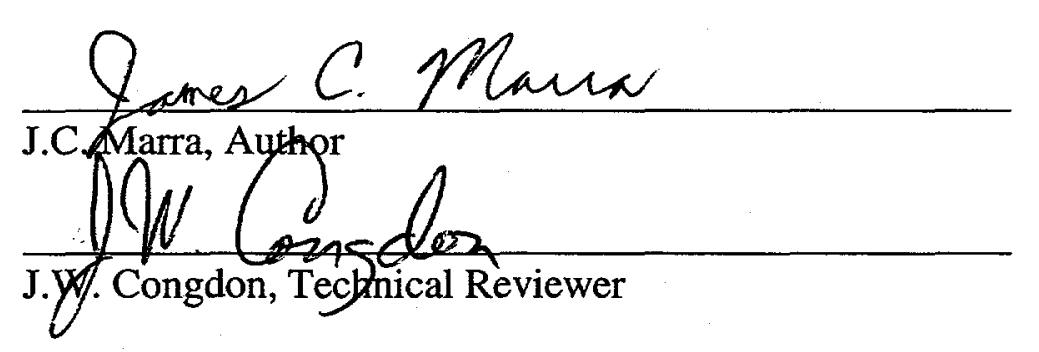

D. Thomm Rashin

D.T. Rankin, Technical Reviewer

Eustaetrahube

E.W. Holtzscheiter, Level 3 Manager, Immobilization Waste Technology
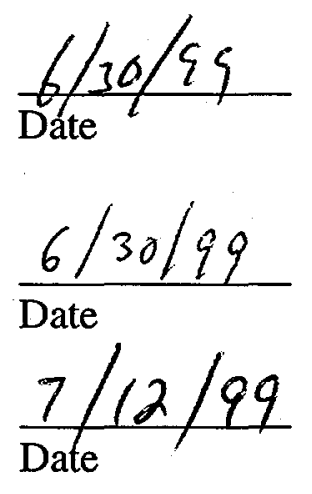

$\frac{6 / 30 / 99}{\text { Date }}$

T/14/a9

Date 


\begin{abstract}
As a result of the end of the Cold War, approximately 50 metric tons of plutonium are no longer needed and have been identified for disposition. A ceramic waste form is the chosen option for immobilization of the excess plutonium. The plutonium ceramic form then will be encased in high-level waste glass using can-in-canister technology for final disposition. The precursor materials are the non-radioactive components that are added to the plutonium feed stream to form the desired phases in the immobilization product. The precursor materials are blended and calcined prior to being mixed with the plutonium feed stream. The purpose of the calcine step is to remove any physical or chemical water retained in the precursors and convert any hydroxides or carbonates to the oxides. Initially, a temperature of $750^{\circ} \mathrm{C}$ for a period of one hour was chosen for the calcining of the precursors. In this effort, several different calcine temperatures were investigated to evaluate the effect on initial phase formation (in the calcined precursors), thermal expansion of the pressed pellets during heating, and mineralogy and porosity of the final product.
\end{abstract}




\section{INTRODUCTION}

As a result of the end of the Cold War, approximately 50 metric tons of weapons useable plutonium are no longer needed by the United States and have been identified for disposition using the can-in-canister technology. A ceramic waste form is the chosen option for immobilization of the excess plutonium. The precursor materials are the non-radioactive components that are added to the plutonium feed stream to form the desired phases in the immobilization product. One of the processing steps in the fabrication of the plutonium ceramic wasteform is the calcining of the precursor materials. The purpose of the calcine step is to remove any physical or chemical water retained in the precursors and convert any hydroxides or carbonates to their respective oxides.

The initial calcining conditions were set at a temperature of $750^{\circ} \mathrm{C}$ for one hour. This study examines the influence of the calcine temperature on phase formation during calcining, thermal expansion of pressed pellets, resulting apparent porosity and final mineralogy ${ }^{1}$.

\section{EXPERIMENTAL PROCEDURE}

Four batches of precursor for the non-radioactive baseline composition were produced. Four calcining temperatures $\left(750,800,850\right.$, and $\left.900^{\circ} \mathrm{C}\right)$ were initially identified to investigate the effect of precursor powders calcined at different temperatures on resulting properties. Table $I$ is the composition of all of the batches produced. The individual batches were separately weighed out, wet milled overnight, dried and screened to $<50$ mesh. The four batches of precursor powder then were combined and mixed. Enough precursor powder to produce three pellets was set aside. The remaining powder was re-divided into five equal batches. The combination and re-division of the powder was performed to ensure uniformity among the batches and to accommodate a fifth calcining temperature of $700^{\circ} \mathrm{C}$.

For each calcining temperature, the precursor powder was spread evenly in an alumina tray. The powder was less than one centimeter deep to achieve even exposure to air and temperature for all of the powder. The powders were heated in air at $5^{\circ} \mathrm{C} /$ minute and held at the calcine temperature for one hour. After calcining, the furnace was turned off and the precursor powders were cooled in the furnace. In this study, cerium oxide (ceria) was used as a surrogate on a mole basis for both plutonium and uranium. To simulate the anticipated "high-firing" of the plutonium feed stream, a sufficient quantity of ceria was heated to $950^{\circ} \mathrm{C}$ and held for two hours.

Samples of each of the calcined precursor powders and the ceria were submitted for X-ray diffraction analysis (XRD). The remaining powder was weighed and the amount of the "highfired" ceria needed was calculated. The appropriate amount of ceria was added to each of the calcined powders. The ceria then was mixed in with the powders; first by mixing in a turbulent mixer for twenty minutes, and then mixed for thirty minutes in an automatic alumina mortar and pestle.

Samples of the mixed powders were submitted for Differential Thermal Analysis (DTA). The powders were lightly packed into an alumina sample holder and heated at $10^{\circ} \mathrm{C} /$ minute to $1350^{\circ} \mathrm{C}$.

Four cylindrical pellets, twelve millimeters in diameter, were pressed from each of the batches. For all of the pellets, a pressing pressure of 10,000 psi was used. The pressed pellets were inspected for physical integrity and discarded if any lamination cracks or end capping was noted.

Three pellets representing each calcining temperature were sintered at the same time. The pellets were placed on a reticulated zirconia board and heated at $5^{\circ} \mathrm{C} /$ minute to $1350^{\circ} \mathrm{C}$. The pellets were held at temperature for four hours and cooled at $5^{\circ} \mathrm{C} /$ minute to $1000^{\circ} \mathrm{C}$ and then 
furnace cooled. The bulk density and apparent porosity of each of the pellets was measured using an ASTM procedure ${ }^{*}$ modified to accommodate small samples. After these measurements were completed, one sintered pellet for each calcine temperature was submitted for XRD analysis.

\section{RESULTS}

The calcined precursor powders without the ceria were analyzed using XRD. Figure 1 shows the XRD patterns for the six calcine temperatures (none; $700 ; 750 ; 800 ; 850$; and $900^{\circ} \mathrm{C}$ ). Table I summarizes the phases that are observed for each calcined precursor powder.

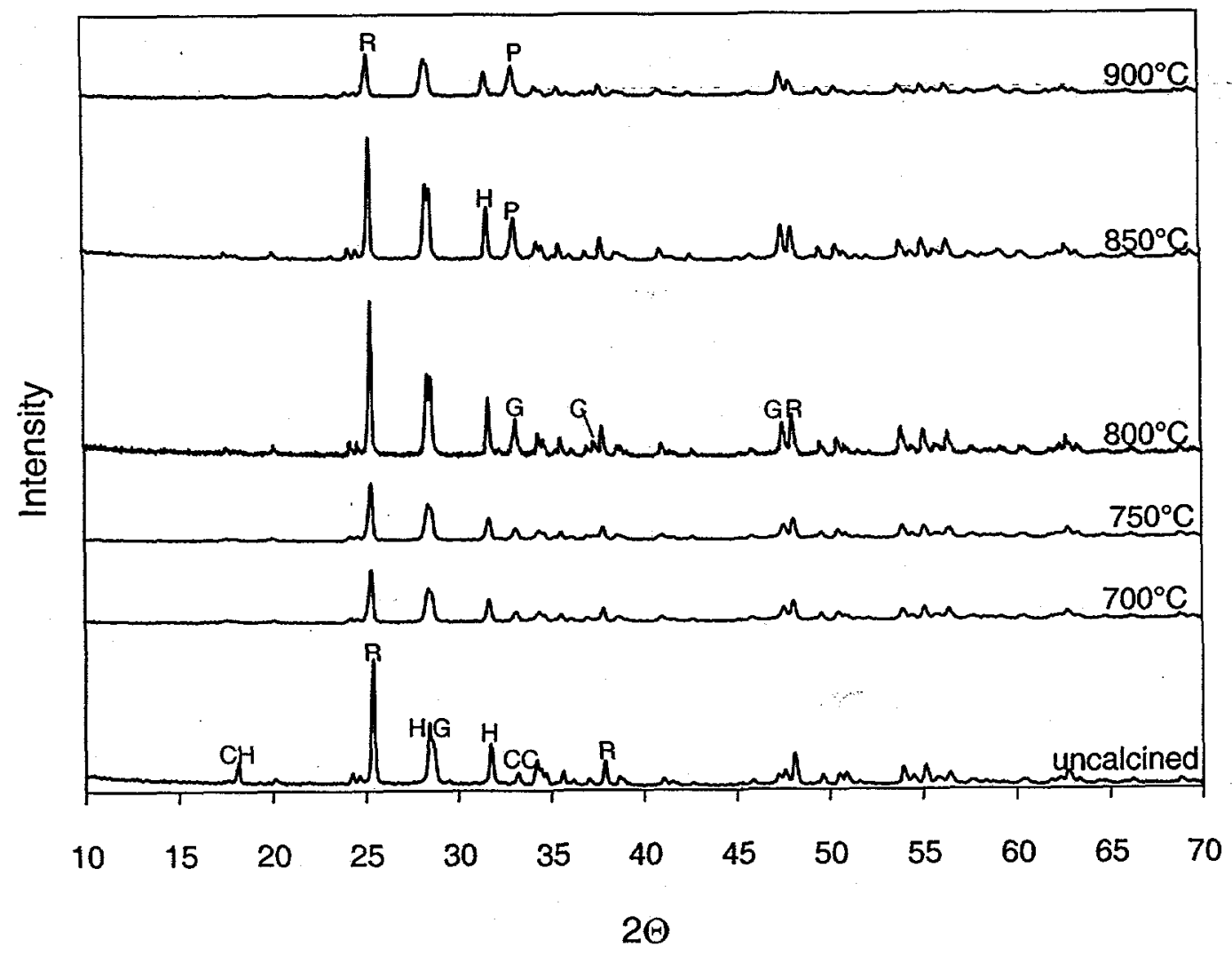

Figure 1. XRD Patterns for precursors calcined at various temperatures. Peaks representative of phases present are marked, R-rutile; P-perovskite; H-hafnia; G-gadolinia; C-calcia; $\mathrm{CH}$ calcium hydroxide; $\mathrm{CC}$-calcium carbonate. 
Table I. Phases Observed Using X-ray Diffraction for Powders at each of the Calcine Temperatures.

\begin{tabular}{|c|l|l|}
\hline $\begin{array}{c}\text { Calcine } \\
\text { Temperature }\end{array}$ & \multicolumn{1}{|c|}{ Phases Observed } & \multicolumn{1}{|c|}{ ICDD* cards } \\
\hline None & $\begin{array}{l}\mathrm{TiO}_{2} \text { (anatase) } \mathrm{HfO}_{2} ; \mathrm{Gd}_{2} \mathrm{O}_{3} ; \\
\mathrm{Ca}(\mathrm{OH})_{2} ; \mathrm{CaCO}_{3}\end{array}$ & $\begin{array}{l}84-1266 ; 34-0104 ; 12-0797 ; 04- \\
0733 ; 05-0586\end{array}$ \\
\hline $700^{\circ} \mathrm{C}$ & $\mathrm{TiO}_{2}$ (anatase); $\mathrm{HfO}_{2} ; \mathrm{Gd}_{2} \mathrm{O}_{3}$ & $84-1266 ; 34-0104 ; 12-0797$ \\
\hline $750^{\circ} \mathrm{C}$ & $\begin{array}{l}\mathrm{TiO}_{2} \text { (anatase); } \mathrm{HfO}_{2} ; \mathrm{Gd}_{2} \mathrm{O}_{3} ; \\
\mathrm{CaO}\end{array}$ & $84-1266 ; 34-0104 ; 12-0797 ; 43-100$ \\
\hline $800^{\circ} \mathrm{C}$ & $\begin{array}{l}\mathrm{TiO} \\
\\
\mathrm{CaO} \text { (anatase) } ; \mathrm{HfO}_{2} ; \mathrm{Gd}_{2} \mathrm{O}_{3} ;\end{array}$ & $84-1266 ; 34-0104 ; 12-0797 ; 43-100$ \\
\hline $850^{\circ} \mathrm{C}$ & $\begin{array}{l}\mathrm{TiO}_{2} \text { (anatase); } \mathrm{HfO}_{2} ; \mathrm{Gd}_{2} \mathrm{O}_{3} ; \\
\mathrm{CaTiO}\end{array}$ & $\begin{array}{l}84-1266 ; 34-0104 ; 12-0797 ; 42- \\
0423\end{array}$ \\
\hline $900^{\circ} \mathrm{C}$ & $\begin{array}{l}\mathrm{TiO}_{2} \text { (anatase) } ; \mathrm{HfO}_{2} ; \mathrm{Gd}_{2} \mathrm{O}_{3} ; \\
\mathrm{CaO} ; \mathrm{CaTiO}_{3}\end{array}$ & $\begin{array}{l}84-1266 ; 34-0104 ; 12-0797 ; 43-100 ; \\
42-0423\end{array}$ \\
\hline
\end{tabular}

*International Center for Diffraction Data

All of the precursor materials were identified in the uncalcined powder. Calcium carbonate also was present. This is a result of the partial carbonation of the calcium hydroxide in air during storage at room temperature.

$$
\begin{gathered}
\mathrm{Ca}(\mathrm{OH})_{2}(\mathrm{~s})+\mathrm{H}_{2} \mathrm{CO}_{3}(\mathrm{~g}) \\
\left(\mathrm{H}_{2} \mathrm{O}+\mathrm{CO}_{2}\right)
\end{gathered} \rightarrow \mathrm{CaCO}_{3}(\mathrm{~s})+2 \mathrm{H}_{2} \mathrm{O}(\mathrm{g}) \Delta \mathrm{G}=-81.48
$$

When the precursor powder is calcined at $700^{\circ} \mathrm{C}$, there are no calcium compounds present in the XRD spectra. During heating, the calcium carbonate and the calcium hydroxide decompose to calcium oxide. Initially the calcium, most likely as calcium oxide, is in an amorphous or very fine scaled crystalline state, not easily detected by x-ray diffraction analysis. When the calcine temperature is increased to $750^{\circ} \mathrm{C}$, the calcium appeared as calcium oxide. At a calcine temperature of $850^{\circ} \mathrm{C}$, perovskite $\left(\mathrm{CaTiO}_{3}\right)$ has formed. When the calcine temperature was increased to $900^{\circ} \mathrm{C}$, there was a significant presence of perovskite and the calcium oxide peak was reduced to slightly above background. This is a result of the calcium being consumed in the formation of the perovskite. High-purity anatase can transition to rutile almost instantaneously at $728^{\circ} \mathrm{C}^{2}$. However, in each of these powders, anatase remained throughout the calcine sequence. The x-ray diffraction pattern of the "high-fired" ceria was identical to that of a sample of ceria that has not been thermally treated.

Thermal dilatometry was used to evaluate the influence of the various calcine temperatures on the thermal expansion of pellets. Figure 2 is all of the thermal expansion curves superimposed on the same graph. The precursors calcined at $700^{\circ} \mathrm{C}$ steadily increased in size until the onset of densification at $\sim 920^{\circ} \mathrm{C}$. Samples made from precursor material calcined at $750^{\circ} \mathrm{C}$ and $800^{\circ} \mathrm{C}$ exhibited an increase in thermal expansion $200-400^{\circ} \mathrm{C}$. The precursors calcined at $750^{\circ} \mathrm{C}$ experienced another increase in thermal expansion near $700^{\circ} \mathrm{C}$. The onset of densification for the precursors calcined at $750^{\circ} \mathrm{C}$ and $800^{\circ} \mathrm{C}$ was also $\sim 920^{\circ} \mathrm{C}$. Thermal expansion of the precursor materials calcined at $850^{\circ} \mathrm{C}$ increased steadily until the onset of densification near $900^{\circ} \mathrm{C}$. When the precursor materials were calcined at $900^{\circ} \mathrm{C}$, the pellet 


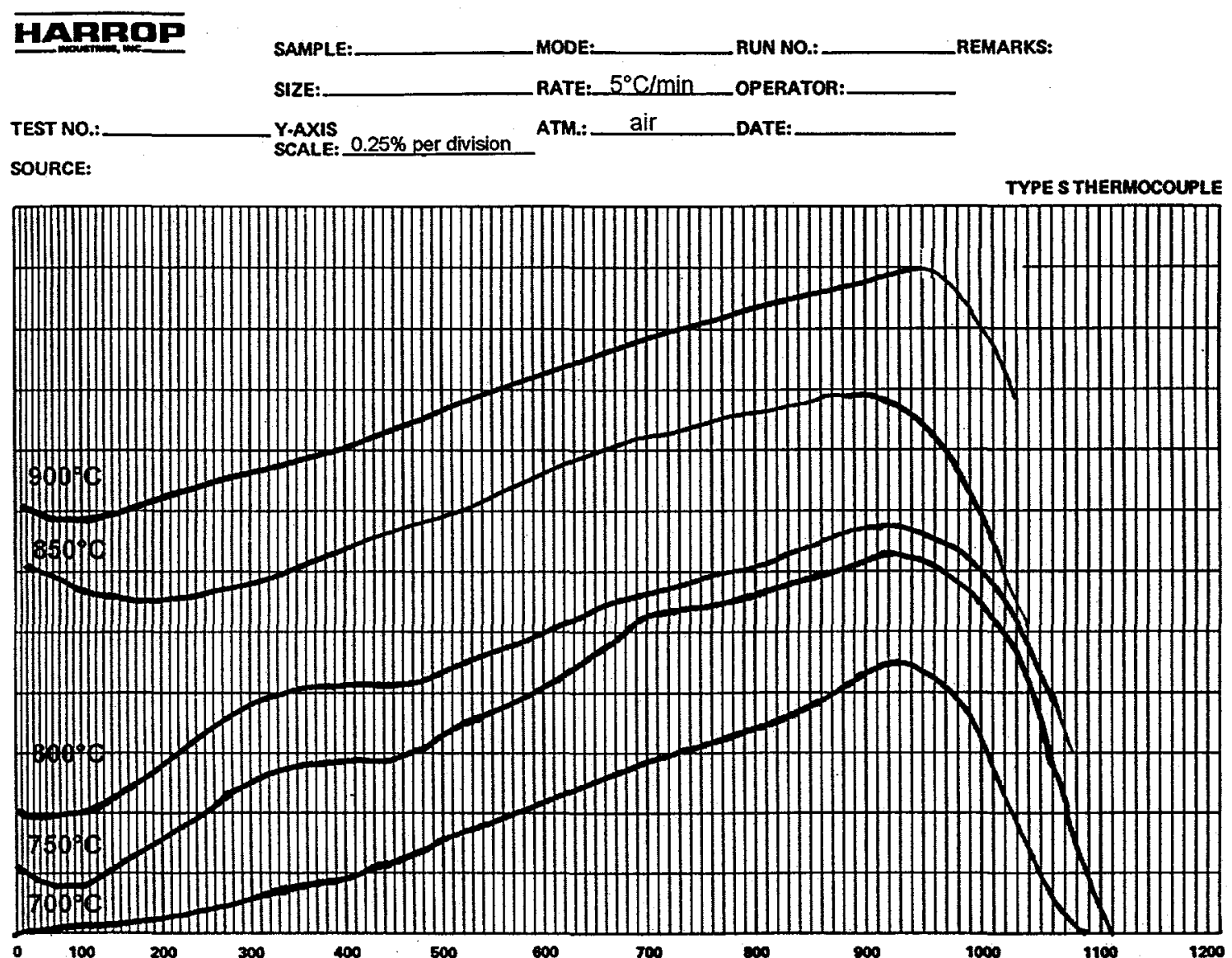

Figure 2. TDA curves for precursor powders calcined at various temperatures (ceria added postcalcine).

expanded steadily until the onset of densification near $930^{\circ} \mathrm{C}$. Table II is the thermal expansion of the precursor materials for the five calcine temperatures investigated.

Table II. Thermal Expansion of the Precursor Materials Calcined at Various Temperatures.

\begin{tabular}{|c|c|}
\hline $\begin{array}{c}\text { Calcine } \\
\text { Temperature }\end{array}$ & $\begin{array}{c}\text { Thermal Expansion (RT - Onset of } \\
\text { Densification) }\end{array}$ \\
\hline $700^{\circ} \mathrm{C}$ & $1.1 \%$ \\
\hline $750^{\circ} \mathrm{C}$ & $1.3 \%$ \\
\hline $800^{\circ} \mathrm{C}$ & $1.2 \%$ \\
\hline $850^{\circ} \mathrm{C}$ & $0.7 \%$ \\
\hline $900^{\circ} \mathrm{C}$ & $1.1 \%$ \\
\hline
\end{tabular}

Differential thermal analysis was performed on each of the calcined powders. Figure 3 plots all of the DTA curves together. The curves have not been corrected for sample size or baseline. 


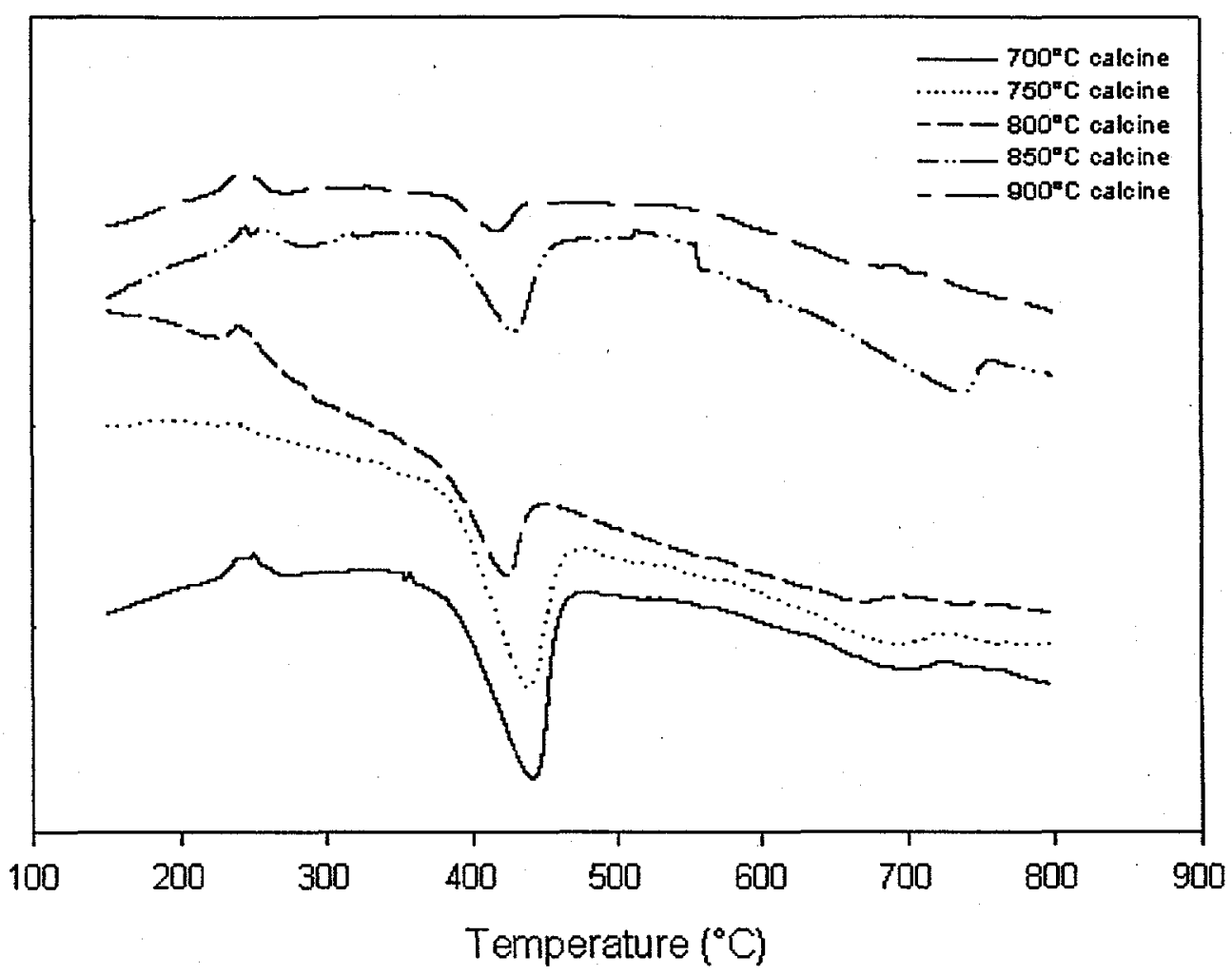

Figure 3. DTA curves for precursor powders calcined at various temperatures (ceria added postcalcine).

The origin of the exothermic event at $250^{\circ} \mathrm{C}$ is an artifact of the equipment. At $250^{\circ} \mathrm{C}$, there is no corresponding mass loss present in the thermogravimetric analysis (TGA) of calcium hydroxide to indicate evolution of a combustible species. Above $400^{\circ} \mathrm{C}$, there is an endotherm that corresponds to the decomposition of calcium hydroxide into calcia and water:

$$
\mathrm{Ca}(\mathrm{OH})_{2}(\mathrm{~s}) \rightarrow \mathrm{CaO}(\mathrm{s})+\mathrm{H}_{2} \mathrm{O}(\mathrm{g}) .
$$

The decomposition temperature range for the calcium hydroxide was determined from the TGA analysis performed on the reagent grade powder, Figure 4 . The initial mass loss is from the above reaction, while the second mass loss event can be attributed to the decomposition of calcium carbonate that has grown into the calcium hydroxide over time. There also appears to be a small gain in mass between $450^{\circ} \mathrm{C}$ and $500^{\circ} \mathrm{C}$. The mass gain is likely due to the ingrowth of calcium carbonate during heating ${ }^{3}$. The final decomposition temperature of calcium hydroxide corresponds well with the literature value of $580^{\circ} \mathrm{C}^{*}$. The total mass loss, $25.1 \%$ corresponds well to the calculated mass loss due to the decomposition of calcium hydroxide into calcia and water, $24.3 \%$. The variation can be attributed to the small amount of calcium carbonate present which has a $44 \%$ mass loss during calcining. The presence of calcium hydroxide in precursor material that has been calcined indicates that some of the calcia formed during calcining reverts to calcium hydroxide. The reaction of calcia with water to form calcium

\footnotetext{
"Decomposition of $\mathrm{Ca}(\mathrm{OH})_{2}$ at $580^{\circ} \mathrm{C}$; CRC Handbook of Chemistry and Physics $71^{\text {st }}$ ed. 1991.
} 
hydroxide results in the evolution of heat and an increase in volume ${ }^{4}$. As the calcine temperature is increased, the magnitude of the endotherm associated with the decomposition of calcium hydroxide is reduced. This indicates that the extent to which equation (2) is reversible is reduced with increased calcine temperatures. It can also be noted that the temperature at which the calcium hydroxide decomposition takes place is reduced with increased calcine temperature.

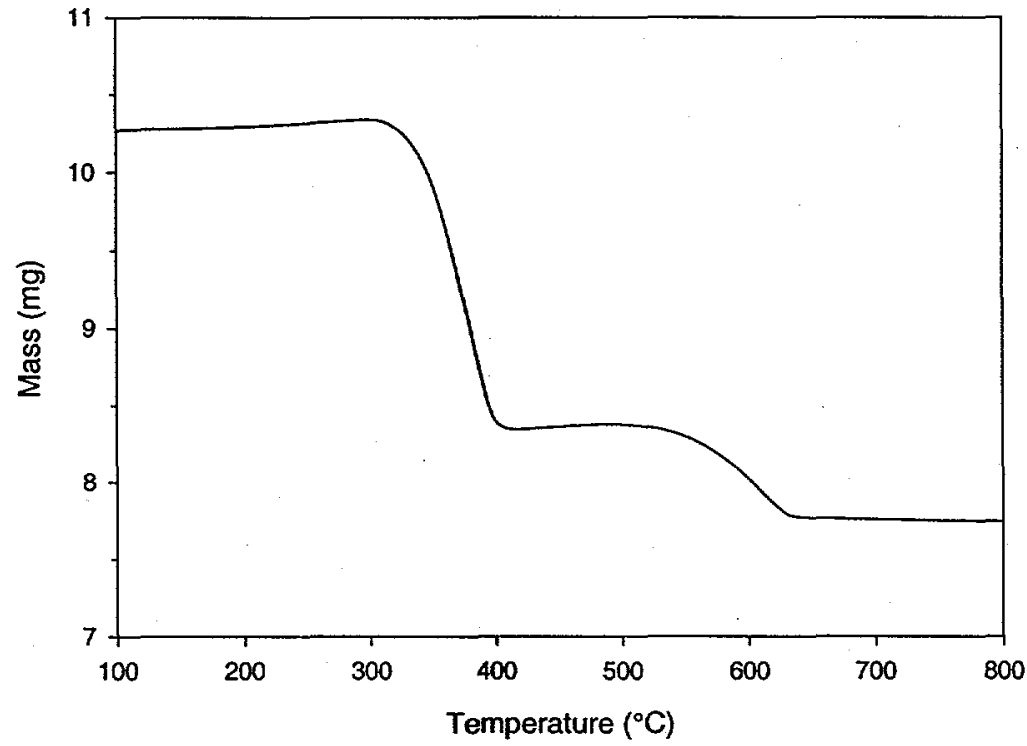

Figure 4. TGA plot for calcium hydroxide.

The apparent porosity and bulk density of the sintered pellets were averaged for the three pellets from each calcine temperature. Table III is the results obtained from the ASTM density tests.

Table III. Properties of Sintered Pellets Prepared with Precursors Calcined at Various Temperatures.

\begin{tabular}{|c|c|c|c|}
\hline $\begin{array}{c}\text { Calcine } \\
\text { Temperature }\end{array}$ & $\begin{array}{c}\text { Apparent } \\
\text { Porosity }\end{array}$ & $\begin{array}{c}\text { Apparent Specific } \\
\text { Gravity }\end{array}$ & $\begin{array}{c}\text { Bulk Density } \\
\left(\mathbf{g} / \mathbf{c m}^{\mathbf{3}}\right)\end{array}$ \\
\hline $700^{\circ} \mathrm{C}$ & $1.41 \%$ & 5.094 & 5.022 \\
\hline $750^{\circ} \mathrm{C}$ & $1.57 \%$ & 4.982 & 4.904 \\
\hline $800^{\circ} \mathrm{C}$ & $0.97 \%$ & 5.063 & 5.014 \\
\hline $850^{\circ} \mathrm{C}$ & $0.80 \%$ & 5.044 & 5.004 \\
\hline $900^{\circ} \mathrm{C}$ & $1.37 \%$ & 5.061 & 4.991 \\
\hline
\end{tabular}

Out of fifteen of pellets analyzed (three pellets for each calcine temperature), only two pellets had an apparent porosity greater than two percent. The apparent specific gravity and bulk density of all of the pellets were comparable.

\section{CONCLUSIONS}

The phases that are formed during the calcination of the precursor materials are dependent on the temperature at which they are calcined. The calcium hydroxide and calcium carbonate present in the uncalcined precursor both decompose before $700^{\circ} \mathrm{C}$. The calcium oxide that is 
formed at $700^{\circ} \mathrm{C}$, however, does not develop enough crystallographically to be observed via $\mathrm{x}-$ ray diffraction analysis under these testing conditions. Perovskite begins to form between 800 $850^{\circ} \mathrm{C}$. No detectable (by XRD) amounts of other intermediate phases are developed among the precursor materials during calcining.

Calcium hydroxide as a batch material is converted to calcia when calcined above $700^{\circ} \mathrm{C}$. However, some calcium hydroxide is reformed, depending on the calcine temperature, through the reversible reaction in equation (2). The amount of calcium hydroxide that reforms and the amount of perovskite that develops both influence the thermal expansion of pressed pellets. The presence of calcium hydroxide increases thermal expansion at low temperatures $\left(200-500^{\circ} \mathrm{C}\right)$, whereas the ingrowth of perovskite reduces the overall thermal expansion. The effect of perovskite is most likely a secondary effect linked to the encumbrance of calcium by perovskite, thus limiting the formation of calcium hydroxide. Calcination of precursor materials at temperatures $>850^{\circ} \mathrm{C}$ can delay the onset of sintering. However, the apparent porosity and bulk density of pellets are unaffected when formed from precursors calcined at different temperatures.

\section{RECOMMENDATIONS}

The calcine temperature does not influence either the bulk density or the mineralogy of sintered one-half inch pellets. The calcine temperature does affect the expansion of the pellets during the initial stages of heating. Based upon these experiments, it is recommended that the precursors be calcined between $750^{\circ} \mathrm{C}$ and $850^{\circ} \mathrm{C}$. At lower calcine temperatures, low temperature expansion of the pellets may be detrimental to the densification of larger scale pellets, whereas higher calcine temperatures delay the onset of densification.

It may also be prudent to consult the process development team for input regarding the effect of the precursor calcine temperature on the powder handling properties.

\section{ACKNOWLEDGEMENTS}

The information contained in this article was developed during the course of work under Contract No. DE-AC09-96SR18500 with the U.S. Department of Energy.

\section{REFERENCES}

${ }^{1}$ GTPU-03-005, Rev. 0 "Baseline Fabrication Process using Wet Milling"

${ }^{2}$ Czanderna, C. N., Ramachandra, R., and Honig, J. M., "The Anatase-Rutile Transition." Trans. Farad. Soc. 54, p 1069 (1958).

${ }^{3}$ A.R. Jurgensen, Personal Communications.

${ }^{4}$ Van Vlack, L.H., Physical Ceramics for Engineers, p. 161 Addison-Wesley Publishing Company, Reading MA. 1964. 